\title{
Empirical Relation between the Turbulent Velocity and the Scale of Phenomenon in the Atmosphere
}

\author{
By Tosio Nan-niti and Tatsuo Konishi \\ Meteorological Research Institute, Tokyo \\ (Manuscript received 27 December 1977, in revised form 9 June 1978)
}

\begin{abstract}
Empirical relation between the turbulent velocity $v$ and the scale of phenomenon $L$ in the atmosphere is obtained as $v \sim L^{1 / 6}$ instead of $\sim L^{1 / 3}$ for the wide range including the inertial subrange, which was expected as well as in the ocean. Then Okubo's experimental diffusion relation, $K \sim L^{1.19}$ for the wide range, instead of $L^{4 / 3}$, is explained by the above relation and the new energy spectrum and auto-correlation function are proposed.
\end{abstract}

\section{Introduction}

The energy dissipation rate, $\varepsilon$, per unit time unit mass can be represented by

$$
\varepsilon \sim v^{3} / \lambda,
$$

where the turbulent velocity, $v$, that is $\left\langle v^{\prime 2}\right\rangle^{1 / 2}$, is r.m.s. turbulent velocity component and $\lambda$ is the scale of eddy. If we take $\varepsilon$ to be constant independently to $\lambda$ in the inertial subrange, then the following relation will be obtained

$$
v \sim \lambda^{1 / 3} .
$$

And the diffusion coefficient, $K$, is described by

$$
K \sim v \lambda \sim \lambda^{4 / 3},
$$

being analogous to the mixing-length hypothesis, and this is the so-called " $4 / 3$ exponent law" (Inoue, 1952).

Nevertheless Nan-niti (1964) presented the experimental result in the ocean that $\varepsilon$ is not constant but changes with the scale of phenomena, $L$, in the following equation

$$
\text { or } \begin{aligned}
& \varepsilon \sim L^{-\alpha}, \\
& v \sim L^{\beta},
\end{aligned}
$$

where $\alpha$ is approximately 0.4 to 0.5 , or $\beta$ is 0.2 to 0.17 over the scale range $10^{2}$ to $10^{7} \mathrm{~cm}$, this scale range sometimes may cover more wide range beyond the inertial subrange. $\mathrm{He}$ used Eq. (1) to calculate the energy dissipation rate without any assumption about scale range but introducing the relationship $\tau \sim L / v$, where $\tau$ is the lifetime of the largest eddy and $L$ may be proportional to its scale. Then $\varepsilon$ may be represented by $\varepsilon \sim v^{2} / \tau \sim v^{3} / L$.

After that, there are some objections to assume $\tau \sim L / v$, or $\varepsilon \sim v^{2} / \tau$ to the outer region of inertial subrange. Still the authors believe their assumption to be reasonable, but conceding the above argument, they use the experimental relation, Eq. (5), only in the following sections.

2. Empirical relation between the turbulent velocity and the scale of phenomenon and power spectrum

The empirical relationship, $v \sim L^{\beta}$, in the ocean was obtained with very few numbers of data and there were some ambiguities about their scales. Available oceanic current data are still very few, so wind data are analyzed, and we use the following equation as the scales of phenomena defined by

$$
L=V \int_{0}^{\tau_{\mid R \rightarrow 0}} R(t) d t,
$$

where $V$ is the mean velocity. In the process of calculation of auto-correlation function $R(t)$, a long trend term was omitted if it was, where $t$ is the time under analysis, and $\tau$ is taken to be $R(t)=0$.

The result of calculation of Eq. (5) with horizontal component is summarized in Table 1 , and is shown in Fig. 1. The value settled in Eq. (5) is obtained by means of the least squares as follows, 
Table 1. Results of the computation of the turbulent velocity and the scale of phenomenon

\begin{tabular}{|c|c|c|c|c|c|c|}
\hline Time & \multirow{2}{*}{$\begin{array}{c}\text { Obs. height } \\
(\mathrm{m})\end{array}$} & \multirow{2}{*}{$\begin{array}{l}\text { Sampling interval } \\
(\mathrm{sec})\end{array}$} & \multirow{2}{*}{$\begin{array}{l}\text { Averaging time } \\
(\mathrm{sec})\end{array}$} & \multirow{2}{*}{$\begin{array}{l}\text { Wind speed } \\
(\mathrm{cm} / \mathrm{sec})\end{array}$} & \multirow{2}{*}{$\begin{array}{l}\left\langle v^{\prime 2}>^{1 / 2}\right. \\
(\mathrm{cm} / \mathrm{sec})\end{array}$} & \multirow{2}{*}{$\begin{array}{c}L \times 10^{3} \\
(\mathrm{~cm})\end{array}$} \\
\hline (a) Nov. 14 1975, & & & & & & \\
\hline $14^{\mathrm{h}} 01.3^{\mathrm{m}}-14^{\mathrm{h}} 02.6^{\mathrm{m}}$ & 5.5 & $1 / 125$ & 0.4 & 517 & 35.5 & 1.178 \\
\hline $\begin{array}{llll}14 & 02.6 & -14 & 03.9\end{array}$ & 5.5 & $1 / 125$ & 0.4 & 510 & 39.7 & 1.484 \\
\hline $\begin{array}{llll}14 & 03.9 & -14 & 05.2\end{array}$ & 5.5 & $1 / 125$ & 0.4 & 524 & 27.9 & 1.378 \\
\hline $\begin{array}{llll}14 & 00 & -14 & 02.6\end{array}$ & 5.5 & $1 / 125$ & 0.8 & 521 & 35.5 & 1.901 \\
\hline $\begin{array}{llll}14 & 02.6 & -14 & 05.2\end{array}$ & 5.5 & $1 / 125$ & 0.8 & 517 & 36.2 & 2.411 \\
\hline $\begin{array}{llll}14 & 05.2 & -14 & 07.8\end{array}$ & 5.5 & $1 / 125$ & 0.8 & 520 & 43.0 & 1.951 \\
\hline $\begin{array}{llll}16 & 05.3 & -16 & 07.9\end{array}$ & 5.5 & $1 / 125$ & 0.8 & 585 & 52.4 & 2.991 \\
\hline $\begin{array}{llll}14 & 00 & -14 & 03.3\end{array}$ & 5.5 & $1 / 125$ & 1.0 & 519 & 34.5 & 1.915 \\
\hline $\begin{array}{llll}14 & 03.3 & -14 & 06.6\end{array}$ & 5.5 & $1 / 125$ & 1.0 & 520 & 38.6 & 3.073 \\
\hline $\begin{array}{llll}14 & 06.6 & -14 & 09.9\end{array}$ & 5.5 & $1 / 125$ & 1.0 & 537 & 48.6 & 3.539 \\
\hline $\begin{array}{llll}14 & 09.9 & -14 & 13.2\end{array}$ & 5.5 & $1 / 125$ & 1.0 & 510 & 40.5 & 3.004 \\
\hline $\begin{array}{llll}16 & 03.3 & -16 & 06.6\end{array}$ & 5.5 & $1 / 125$ & 1.0 & 602 & 52.6 & 3.395 \\
\hline $\begin{array}{llll}16 & 06.6 & -16 & 09.9\end{array}$ & 5.5 & $1 / 125$ & 1.0 & 561 & 37.5 & 1.442 \\
\hline $\begin{array}{llll}16 & 09.9 & -16 & 13.2\end{array}$ & 5.5 & $1 / 125$ & 1.0 & 570 & 48.1 & 3.346 \\
\hline $1400 \quad-14 \quad 20$ & 5.5 & $126 / 125$ & 3.024 & 520 & 44.0 & 5.127 \\
\hline-1520 & 5.5 & $126 / 125$ & 3.024 & 586 & 53.9 & 12.48 \\
\hline-1540 & 5.5 & $126 / 125$ & 3.024 & 622 & 52.1 & 9.498 \\
\hline-1620 & 5.5 & $126 / 125$ & 3.024 & 567 & 49.2 & 7.388 \\
\hline-1334 & 5.5 & $126 / 125$ & 10.08 & 411 & 38.5 & 10.6 \\
\hline-1434 & 5.5 & $126 / 125$ & 10.08 & 538 & 42.4 & 17.4 \\
\hline-1534 & 5.5 & $126 / 125$ & 10.08 & 596 & 44.2 & 14.9 \\
\hline $\begin{array}{llll}16 & 00 & -16 & 34\end{array}$ & 5.5 & $126 / 125$ & 10.08 & 567 & 44.7 & 15.6 \\
\hline (b) Nov. 14 1974, & & & & & & \\
\hline $10^{\mathrm{h}} 01^{\mathrm{m}}-11^{\mathrm{h}} 01^{\mathrm{m}}$ & 5.0 & 30.0 & - & 615 & 115.4 & 18.3 \\
\hline $\begin{array}{llll}20 & 20 & -21 & 20\end{array}$ & 5.0 & 30.0 & - & 540 & 88.2 & 44.7 \\
\hline (c) Nov. 15 1974, & & & & & & \\
\hline $03^{\mathrm{h}} 50^{\mathrm{m}}-04^{\mathrm{h}} 50^{\mathrm{m}}$ & 5.0 & 30.0 & - & 199 & 34.4 & 12.9 \\
\hline (d) Oct. 30 1967, & & & & & & \\
\hline $15^{\mathrm{h}} 01^{\mathrm{m}}-18^{\mathrm{h}} 45^{\mathrm{m}}$ & 0.5 & 60.0 & - & 559 & 72.8 & 81.8 \\
\hline $\begin{array}{llll}15 & 01 & -18 & 45\end{array}$ & 1.0 & 60.0 & - & 557 & 63.2 & 65.8 \\
\hline $\begin{array}{llll}15 & 01 & -18 & 45\end{array}$ & 2.0 & 60.0 & - & 638 & 70.7 & 84.2 \\
\hline $\begin{array}{llll}15 & 01 & -18 & 45\end{array}$ & 4.0 & 60.0 & - & 656 & 72.8 & 89.8 \\
\hline $\begin{array}{llll}15 & 01 & -18 & 45\end{array}$ & 6.0 & 60.0 & - & 650 & 74.2 & 79.2 \\
\hline $\begin{array}{llll}19 & 36 & -23 & 45\end{array}$ & 0.5 & 60.0 & - & 540 & 86.6 & 103.0 \\
\hline $\begin{array}{llll}19 & 36 & -23 & 45\end{array}$ & 1.0 & 60.0 & - & 547 & 71.4 & 92.6 \\
\hline $\begin{array}{llll}19 & 36 & -23 & 45\end{array}$ & 2.0 & 60.0 & - & 592 & 87.7 & 111.5 \\
\hline $\begin{array}{llll}19 & 36 & -23 & 45\end{array}$ & 4.0 & 60.0 & - & 633 & 85.6 & 121.9 \\
\hline $\begin{array}{llll}19 & 36 & -23 & 45\end{array}$ & 6.0 & 60.0 & - & 644 & 88.3 & 136.2 \\
\hline (e) Oct. 31 1967, & & & & & & \\
\hline $00^{\mathrm{h}} 11^{\mathrm{m}}-04^{\mathrm{h}} 45^{\mathrm{m}}$ & 0.5 & 60.0 & - & 447 & 90.0 & 185.0 \\
\hline $\begin{array}{llll}00 & 11 & -04 & 45\end{array}$ & 1.0 & $60: 0$ & - & 457 & 72.1 & 161.5 \\
\hline $\begin{array}{llll}00 & 11 & -04 & 45\end{array}$ & 2.0 & 60.0 & - & 494 & 81.2 & 214.9 \\
\hline $\begin{array}{llll}00 & 11 & -04 & 45\end{array}$ & 4.0 & $60: 0$ & - & 537 & 82.5 & 218.8 \\
\hline $\begin{array}{llll}00 & 11 & -04 & 45\end{array}$ & 6.0 & 60.0 & - & 552 & 81.2 & 238.2 \\
\hline
\end{tabular}

Data (a), (b) and (c) were obtained from Ito Marine Observation Tower, and Data (d) and (e) from the Buoy off Kishu. The intsruments used were the sonic anemometer for Data (a) and the cup anemometer for Data (b)-(e). Numbers of data averaged are 200 to 400 .

$$
v \sim 10.5 \times L^{0.17} \pm 11.3 .
$$

Then the value $\beta$ is $0.17 \simeq 1 / 6$ over the scale range $10^{3}$ to $10^{5} \mathrm{~cm}$. This is quite the same result as expected by the analogy between the ocean and the atmosphere.
Next, by Eqs. $K \sim v L$ and (7), we have

$$
K(L) \sim L^{7 / 6} .
$$

Here Eq. (8) was already supported by Okubo's empirical formula $K \sim l^{1.19}$ for the range of $l=$ $10^{3}$ to $10^{9} \mathrm{~cm}$ in the ocean, where $l$ is propor- 


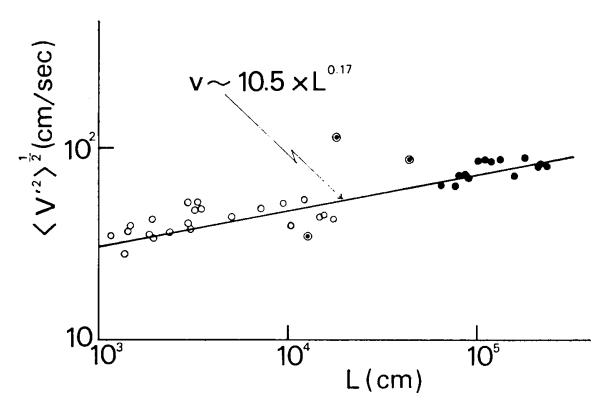

Fig. 1 Relationship between turbulent velocity and scale of turbulence.

with sonic anemometer at the Ito Marine Observation Tower.

$\odot$ with cup anemometer at the Ito Marine Observation Tower.

with cup anemometer mounted to the buoy from the Research vessel "Ryofu Maru" off Kishu.

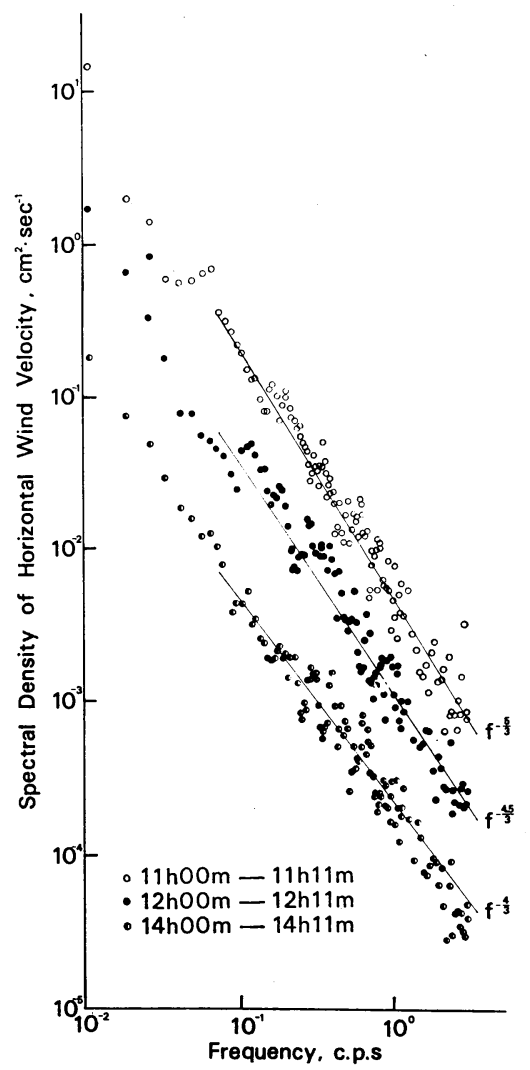

Fig. 2 Spectra of horizontal wind component at the Ito Marine Observation Tower. The energy density scale is shown for the upper spectrum. The other spectra are displaced in step of $10 \mathrm{~cm}^{2} \mathrm{sec}^{-1}$. tional to $L$ (Okubo, 1962; Nan-niti, 1970). So the application of "the mixing-length hypothesis, $K \sim v L$," to our wide range problem may be permissible, that is, Eq. (8) will be held over the more wide range including the inertial subrange.

From the empirical relation, $v \sim L^{1 / 6}$, the energy spectrum $F(f)$ and the auto-correlation function $R(t)$ will be obtained

$$
\begin{aligned}
& F(f) \sim f^{-4 / 3}, \\
& R(t) \sim 1-(t / \tau)^{1 / 3},
\end{aligned}
$$

where $f$ is the wave frequency.

Then the power spectra of horizontal and vertical velocity were computed using the Fast Fourier Transform method. The each total duration of the run was usually about 40 minutes, those periods appeared most steady direction in time. The duration of time for computing the spectra in digital form, as a rule, was 11 minutes for convenient sake of calculation. So several selections were made as follows.

The power spectra are shown in Fig. 2 and 3. Their exponent values obeying to power law are obtained by least square fit and summarized in Table 2 , which support equally the both equations, $-5 / 3$ or $-4 / 3$ power law.

Many examples were reported by Inoue et al. (Inoue, Tani, and Imai, 1955) that auto-correlation functions were expressed as $R(t) \sim t^{2 / 3}$ and

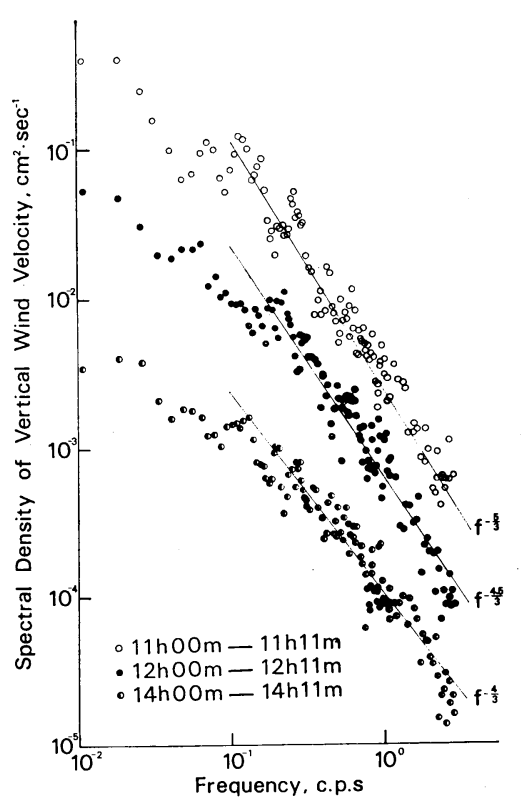

Fig. 3 Spectra of vertical wind component. The other explanations are of the same as Fig. 2. 
Table 2. Results of the computation of the exponent of the wind energy spectra

\begin{tabular}{cccccc}
\hline Time & $\begin{array}{c}\text { Sampling } \\
\text { interval } \\
(\mathrm{sec})\end{array}$ & $\begin{array}{c}\text { Averaging } \\
\text { time } \\
(\mathrm{sec})\end{array}$ & $\begin{array}{c}\text { Number } \\
\text { of data } \\
\text { averaged }\end{array}$ & $\begin{array}{c}\text { Exponent } \\
\text { (Horizontal } \\
\text { Comp.) }\end{array}$ & $\begin{array}{c}\text { Exponent } \\
\text { (Vertical } \\
\text { Comp.) }\end{array}$ \\
\hline Nov. 141975, & & & & & \\
$11^{\mathrm{h}} 00^{\mathrm{m}}-11^{\mathrm{h}} 11^{\mathrm{m}}$ & $1 / 125$ & $40 / 125$ & 8192 & $-4.82 / 3$ & $-4.86 / 3$ \\
$12^{\mathrm{h}} 00^{\mathrm{m}}-12^{\mathrm{h}} 11^{\mathrm{m}}$ & $1 / 125$ & $40 / 125$ & 8192 & $-4.64 / 3$ & $-4.44 / 3$ \\
$14^{\mathrm{h}} 00^{\mathrm{m}}-14^{\mathrm{h}} 11^{\mathrm{m}}$ & $1 / 125$ & $40 / 125$ & 8192 & $-4.30 / 3$ & $-3.84 / 3$ \\
\hline
\end{tabular}

Table 3. Ratios of some turbulence factors taking $\beta=1 / 3$ and $\beta=1 / 6$ as function of $\mathrm{L}$

\begin{tabular}{c|rrrrrrr}
\hline $\mathrm{L}(\mathrm{cm})$ & $10^{0}$ & $10^{1}$ & $10^{2}$ & $10^{3}$ & $10^{4}$ & $10^{5}$ & $10^{6}$ \\
\hline$v_{\beta=1 / 6} / v_{\beta=1 / 3}=K_{\beta=1 / 6} / K_{\beta=1 / 3}=L^{-1 / 6}$ & 1 & 0.68 & 0.46 & 0.32 & 0.22 & 0.15 & 0.10 \\
\hline
\end{tabular}

$t^{1 / 3}$. About the latter $1 / 3$ power result, they (Inoue et al.) said that "The theoretical basis of these results is not yet clear," but these results are expected by the present authors' Eq. (10).

\section{Discussion}

Now the ratios of some turbulence factors such as $v_{\beta=1 / 6} / v_{\beta=1 / 3}\left(=K_{\beta=1 / 6} / K_{\beta=1 / 3}=L^{-1 / 6}\right)$ are tabulated as function of $L$ by Eqs. (3), (5) and (8) in Table 3.

Table 3, shows that the real experimental diffusion coefficient will be one order smaller than the value which expected by $4 / 3$ power law when the scale of phenomenon is $L=10^{6} \mathrm{~cm}$. As mentioned above, this result was already supported by Okubo's empirical formula $K \sim L^{1.19}$. In the field experiments of diffusion, there may be many cases that the scale of phenomena may not be in the inertial subrange, but in the more larger scale range. So Eq. (8) must be used instead of $4 / 3$ power law.

About the energy spectrum and the auto-correlation function, they are something complicated. As seen by Eq. (7) and Fig. 1, the standard deviation of the turbulent velocity as the function of scale is not small. The value of $\beta$ in Eq. (5) may take variable ones, about $1 / 6 \sim 1 / 3$, if the readers see some narrow scale ranges. So the both results such as $-5 / 3$ or $-4 / 3$ exponent for energy spectrum and $2 / 3$ or $1 / 3$ exponent for auto-correlation function will be obtained in the cases of small range. But $\beta$ takes $1 / 6$ clearly, especially when the readers see the pheno- mena over more wider range.

Again we emphasize the generalized turbulent diffusion theory governed by Eqs. (7), (8), (9) and (10), which will cover the more wide scale range.

\section{Conclusion}

The experimental relation between the turbulent velocity and the scale of turbulence in the atmosphere fell the authors' expectation quite well, that is $v \sim L^{1 / 6}$, and the result will also be supported by Okubo's experimental result of diffusion. New proposed spectrum calculated from the above relation was also obtained by the experiment.

\section{References}

Inoue, E., 1952: On the structure of wind near the ground. (In Japanese with English abstract), Bull. Nat. Inst. Agricul. Sci. Series A, No. 2, 1-93.

- N. Tani and K. Imai, 1955: Measurements of the wind turbulence over cultivated fields. (In Japanese with English abstract), Bull. Nat. Inst. Agricul. Sci. Series A. No. 4, 1-36.

Nan-niti, T., 1964: Oceanic turbulence. Oceanogr. Mag., 16, 35-45.

- 1970: A hypothesis of turbulent energy spectrum. J. Oceanogr. Soc. Japan, 26, 296-299.

Okubo, A., 1962: Horizontal diffusion from an instantaneous point-source due to oceanic turbulence. Tech. Rep., 32, 1-124, Chesapeake Bay Institute. 


\title{
大気中における乱れの速度と現象スケールとの実験式
}

\author{
南 日俊 夫・小西達男
}

気象研究所

著者の一人, 南日は1964年海洋に执いて乱れの速度と現象のスケールとの関係式は, 広い範囲については, スケー ルの $1 / 3$ 乗ではなくて $1 / 6$ 乗に比例する事を見出したが，同じ関係が大気についても成立する事をたしかめた。

この結果は大久保の拡散の実験式, 1.19 乗則を支持し, またエネルギースペクトルはー4/3 乗則, 自己相関関数は $1 / 3$ 乗則が期待される。スペクトルの計算結果はー $4 / 3$ 乗則もー $5 / 3$ 乗則も同じよらにみられたが, 要は乱れの速度が スケールの $1 / 3$ 乗則, 或は, $1 / 6$ 乗則にのるかによるもので, 狭いスケールの時は $-5 / 3$ 乗からー4/3 乗則の範囲に, 広いスケールにわたるものはー4/3 乗則によると考えられる。 